This is a self-archived version of an original article. This version may differ from the original in pagination and typographic details.

Author(s): Owen, Patrick J; Hangai, Mika; Kaneoka, Koji; Rantalainen, Timo; Belavy, Daniel L.

Title: Mechanical loading influences the lumbar intervertebral disc : A cross-sectional study in 308 athletes and 71 controls

Year: 2021

Version: Accepted version (Final draft)

Copyright: (c) 2020 Wiley

Rights: In Copyright

Rights url: http://rightsstatements.org/page/InC/1.0/?language=en

Please cite the original version:

Owen, P. J., Hangai, M., Kaneoka, K., Rantalainen, T., \& Belavy, D. L. (2021). Mechanical loading influences the lumbar intervertebral disc : A cross-sectional study in 308 athletes and 71 controls. Journal of Orthopaedic Research, 39(5), 989-997. https://doi.org/10.1002/jor.24809 
Patrick Owen ORCID iD: 0000-0003-3924-9375

Daniel Belavy ORCID iD: 0000-0002-9307-832X

\title{
Mechanical loading influences the lumbar intervertebral disc. A cross-sectional study in 308 athletes and 71 controls
}

\author{
Patrick J Owen ${ }^{1} P h D$ \\ Mika Hangai ${ }^{2} M D, P h D$ \\ Koji Kaneoka ${ }^{3} M D, P h D$ \\ Timo Rantalainen ${ }^{1,4} P h D$ \\ Daniel L Belavy ${ }^{1} P h D$
}

${ }^{1}$ Deakin University, Institute for Physical Activity and Nutrition, School of Exercise and Nutrition Sciences, Geelong, Victoria, Australia

${ }^{2}$ Japan Institute of Sports Sciences, Sports Medical Center, Department of Orthopaedic Surgery, Tokyo, Japan

${ }^{3}$ Waseda University, Faculty of Sport Sciences, Tokorozawa, Japan

${ }^{4}$ Gerontology Research Centre and Faculty of Sport and Health Sciences, University of Jyväskylä, Jyväskylä, Finland

Corresponding author: A/Prof Daniel L Belavy, PhD; Deakin University, Institute for Physical Activity and Nutrition, School of Exercise and Nutrition Sciences, 221 Burwood Highway, Burwood, Victoria, 3125, Australia. Tel: +61 39244 6606; Fax: +61 39244 6017; E-mail: d.belavy@ deakin.edu.au, belavy@gmail.com.

Emails: p.owen@deakin.edu.au; mika.hangai@jpnsport.go.jp; kaneoka@waseda.jp; timo.rantalainen@jyu.fi; d.belavy@deakin.edu.au; belavy@gmail.com

Short title: Sport-specific IVD adaptation

Author contributions: Study design: $\mathrm{MH}, \mathrm{KK}$. Study conduct: MH, KK. Data collection: MH, KK. Data analysis: PO, TR, DB. Data interpretation: PO, MH, KK,

This article has been accepted for publication and undergone full peer review but has not been through the copyediting, typesetting, pagination and proofreading process, which may lead to differences between this version and the Version of Record. Please cite this article as doi: 10.1002/jor.24809.

This article is protected by copyright. All rights reserved. 
TR, DB. Drafting manuscript: PO, DB. Revising manuscript content: PO, MH, KK, TR, DB. Approving final version of manuscript: PO, MH, KK, TR, DB.

Conflict of interest: All authors declare they have no conflicts of interest.

Acknowledgements: This study was supported by a Grant-in-Aid for Scientific Research (B) from the Japan Society for the Promotion of Science (grant number: 19300220). Gerontology Research Center is a joint effort between the University of Jyväskylä and the University of Tampere.

\begin{abstract}
There is evidence in animal populations that loading and exercise can positively impact the intervertebral disc (IVD). However, there is a paucity of information in humans. We examined the lumbar IVDs in 308 young athletes across six sporting groups (baseball, swimming, basketball, kendo, soccer and running; mean age 19yrs) and 71 non-athletic controls. IVD status was quantified via the ratio of IVD to vertebral body height (IVD hypertrophy) and ratio of signal intensity in the nucleus to that in the annulus signal (IVD nucleus hydration) on sagittal T2-weighted MRI. Pvalues were adjusted via the false discovery rate method to mitigate false positives. In examining the whole collective, compared to referents, there was evidence of IVD hypertrophy in basketball $(\mathrm{P} \leq 0.029)$, swimming $(\mathrm{P} \leq 0.010)$, soccer $(\mathrm{P}=0.036)$ and baseball $(\mathrm{P}=0.011)$ with greater IVD nucleus hydration in soccer $(\mathrm{P}=0.007)$. After matching participants based on back-pain status and body height, basketball players showed evidence of IVD hypertrophy $(\mathrm{P} \leq 0.043)$ and soccer players greater IVD nucleus hydration $(\mathrm{P}=0.001)$ than referents. Greater career duration and training volume correlated with less (i.e. worse) IVD nucleus hydration, but explained less than $1 \%$ of the variance in this parameter. In this young collective, increasing age was associated with increased IVD height. The findings suggest that basketball and soccer may be associated with beneficial adaptations in the IVDs in young athletes. In line with evidence on other tissues, such as muscle and bone, the current study adds to evidence that specific loading types may beneficially modulate lumbar IVD properties.
\end{abstract}

Key words: Sports; Spine; Magnetic resonance imaging; Exercise; Back Pain; Low Back Pain; Intervertebral Disc

\title{
INTRODUCTION
}

Tissues, such as bone, that play a role in transmitting mechanical load, adapt to the load applied to them ${ }^{1}$. Similarly, the exercise training principle of specificity postulates that physiological adaptations will only occur when the tissue of interest is targeted and stressed ${ }^{2}$. For example, progressive resistance exercise training can increase the size of muscle (i.e. hypertrophy) ${ }^{3}$, whereas impact-loading exercise training has been shown to increase bone mineral density ${ }^{4}$.

However, there is limited evidence in humans of which exercise training modalities target and stress the intervertebral disc (IVD). Studies of IVD tissue and cells in vitro

This article is protected by copyright. All rights reserved. 
have shown that loading can result in anabolic responses ${ }^{5,6}$, specifically cyclical loads of 0.2-0.8 megapascal, at $0.1-1.0 \mathrm{~Hz}$ for up to eight hours/day was considered in one review of the field to lead to an anabolic response of the IVD ${ }^{5}$. Animal studies reported beneficial modulation of the IVD with exercise: three months of exercises in adult dogs improved IVD uptake of glucose, oxygen and glycogen ${ }^{7}$ and eight weeks of treadmill- exercise in rats increased IVD matrix production ${ }^{8}$ and cell numbers in the IVD stem cell niche and the outer annulus ${ }^{9}$. A further study of 11 weeks treadmill exercises in rats found increased IVD glycosaminoglycan concentration ${ }^{10}$. Moreover, treadmill exercises of injured and sham IVDs in rats stimulated cell proliferation in both groups ${ }^{11}$. These animal data support a positive impact of locomotive exercise on the IVD of quadrupedal animals.

Studies in human athletic populations have shown that certain types of exercise or loading can be detrimental for the IVD. For example, greater lumbar IVD degeneration was observed in gymnasts compared to non-athlete controls ${ }^{12}$, as well as in weight lifters and soccer players compared to shooters ${ }^{13}$. Moreover, exercise training load appears to be associated with lumbar IVD degeneration, with elite swimmers shown to have a greater prevalence of degeneration compared to recreational swimmer referents ${ }^{14}$. However, data on a beneficial impact of exercise in humans on the IVD is less conclusive.

Emerging evidence supports the notion that certain types of exercise training may be beneficial to lumbar IVD characteristics ${ }^{15}$. For example, high-volume cycling ${ }^{16}$ and long-distance running and jogging ${ }^{15}$ were shown to be associated with better lumbar IVD hydration and glycosaminoglycan levels (i.e. greater IVD T2-times ${ }^{17}$ ) compared to non-athletic controls. Additionally, long-distance runners had a greater IVD height relative to vertebral body height, which suggests IVD hypertrophy in response to prolonged exposure to long-distance running ${ }^{15}$. These findings were replicated in middle-aged adults ${ }^{18}$, which suggests beneficial adaptations from specific types of loading may combat age-related deterioration of IVDs. Furthermore, recent evidence ${ }^{19}$ showed that people who perform vigorous physical activity are have, on average, greater T2-times and apparent diffusion co-efficients in the lumbar IVDs, implying greater hydration and glycosaminoglycan levels. Whilst these data provide initial evidence of a potentially beneficial effect of specific kinds of exercise on the IVD, the breadth of the evidence is limited. Similarly, the sample size of these prior studies was typically small, which may limit generalisability.

We aimed to examine the adaptation of the IVD in a range of sporting types, in addition to non-athlete controls in a large sample size. We hypothesised that participation in sports involving upright load-bearing activities, such as running, would be associated with more beneficial IVD characteristics than non-athletic referents.

\section{MATERIALS AND METHODS}

This study was approved by the Ethical Committee of the Graduate School of Comprehensive Human Sciences, University of Tsukuba (notification number: 100)

This article is protected by copyright. All rights reserved. 
and the Deakin University Human Research Ethics Committee (reference number: 2017-257). All participants provided their informed written consent prior to participation. This research complied with the Australia Code for the Responsible Conduct of Research (2018).

\section{Participants}

We selected a range of sports that we expected would apply different habitual physical loading to their lumbar spine. Well-trained (i.e. participation for greater than five years) male and female athletes across six sporting codes (baseball, swimming, basketball, kendo, soccer and running) who spent a minimum of 5 years in their sport were included in the study ${ }^{20}$. Non-athletic controls included those who had not participated in competitive sport more than three times per week throughout their lifetime. Participants were excluded if they had previously undergone spine surgery. Lifetime low back pain status (yes/no), height and weight, career duration and training load (days per week, hours per day) were assessed via subjective questionnaire.

\section{Magnetic resonance imaging, image processing and analysis}

To quantify IVDs, a T2-weighted, density-weighted, fast spin-echo sagittal sequence (thickness, $6.0 \mathrm{~mm}$; interslice distance, $0 \mathrm{~mm}$; repetition time, $4000 \mathrm{~ms}$; echo time, $125 \mathrm{~ms}$; field of view, $300 \times 300 \mathrm{~mm}, 256$ × 256 pixels) was used on a 0.2-T Imager scanner (AIRIS Mate, Hitachi Medical AG, Tokyo, Japan). Data were exported for offline processing. A single midline slice was used in further processing. ImageJ 1.52a (http://rsb.info.nih.gov/ij/) was used to perform all quantitative MRI measures with the examiner blinded to group allocation (a random number, obtained from www.random.org, was assigned to each image). After segmenting the IVD, a custom written ImageJ plugin ("ROI Analyzer"; https://github.com/tjrantal/RoiAnalyzer and https://sites.google.com/site/daniellbelavy/home/roianalyser) was used to rotate the region of interest (ROI) to the horizontal and measure height and signal intensity of the IVD as a whole, as well as in five subregions from anterior to posterior (Figure 1). Subregions were calculated by the custom written plugin to be of equal width from the most anterior and most posterior point of the rotated ROI. Height was calculated as the average number of pixels in each vertical pixel column of the rotated ROI (for the whole IVD and also within each subregion). To obtain the height of the vertebral body from L1 to L5, similar measurements were performed. The ratio of IVD height to the height of the superior vertebral body was then calculated (as a measure of IVD hypertrophy, normalised to the height of the vertebral body; as performed in prior work ${ }^{15}$ ). To assess the relative hydration of the nucleus and account for variation between scans on T2-weighted imaging, we used an approach established in prior work ${ }^{21}$ and calculated the ratio of signal intensity in the nuclear region to the mean of anterior and posterior annulus (as a measure of the relative hydration of the nucleus). The angle of the region of interest fitted to the IVD relative to the horizontal was calculated for each IVD. All levels from L1/2 to L5/S1 were measured. An average of all lumbar levels was also calculated. Lumbar lordosis was calculated as the angle between the L1/2 and L5/S1 IVDs. Primary analysis focussed on (a) the ratio of IVD

This article is protected by copyright. All rights reserved. 
height to vertebral body height and (b) the ratio of signal intensity between the nucleus and annulus.

\section{Statistical analyses}

All analyses were conducted using STATA statistical software version 15 (College Station TX, USA). Measures were compared between athletic groups and controls by one-way analysis of covariance with participant height as a covariate or chi-square test. Additionally, due to differences between participant groups for body height, IVD parameters were assessed between-group using one-way analysis of variance of participants matched based on low back pain status (yes/no) and height within $2 \mathrm{~cm}$ ( $n=22$ per group). The latter approach accounted for the effect of body size variance on spinal parameters, in particular body height, which has been shown to vary among athletic groups ${ }^{22}$. Similar supplemental analysis of all athletic groups pooled versus control was also performed. The strength and direction of associations between IVD parameters and anthropometric data and training load variables were assessed by Pearson correlation coefficient and partial Pearson correlation coefficient adjusting for age, height and sex. Analyses used IVD outcomes (a) averaged across all lumbar vertebral levels, and (b) at each individual lumbar vertebral level. To mitigate the risk of type I errors, all P-values were adjusted by the false discovery rate method ${ }^{23}$. An alpha-level of 0.05 was adopted for all statistical tests.

\section{RESULTS}

The total sample analyses consisted of 308 athletes and 71 controls, with matchedanalyses included 22 athletes per group (total athletes: $n=132$ ) and 22 controls (Table 1). Mean (range) age of the total sample was 20 (18-24) years. All sporting groups had greater height than control (all: $\mathrm{P}<0.01)$. The running and swimming groups also had a $12 \%(\mathrm{P}=0.004)$ and $8.5 \%(\mathrm{P}=0.013)$ greater prevalence of back pain compared to controls, respectively.

\section{IVD and spine properties in the total sample}

In the total sample, average and individual lumbar IVD tended to have greater height in the baseball (7.0-10\%, all: $\mathrm{P} \leq 0.009)$, basketball (8.4-17\%, all: $\mathrm{P} \leq 0.013$ ), soccer (5.8-9.0\%, all: $\mathrm{P} \leq 0.020)$ and swimming (7.0-9.0\%, all: $\mathrm{P} \leq 0.014)$ groups, compared to controls. Similarly, average lumbar IVD width was greater compared to controls for the baseball $(5.9 \%, \mathrm{P}=0.008)$ and basketball $(6.6 \%, \mathrm{P}=0.003)$ groups (Table 1$)$. Lumbar lordosis was less (lumbar spine flatter) in the swimming group only.

For the primary outcomes of focus (Table 2; Figure 2), average lumbar IVD height to vertebral body height ratio was $7.6 \%$ greater than controls in both the basketball $(\mathrm{P}=0.001)$ and swimming $(\mathrm{P}=0.001)$ groups (Table 2$)$. Similarly, greater individual IVD height to vertebral body height ratio was observed compared to controls for basketball (6.3-14\%, all: $\mathrm{P} \leq 0.029)$ and swimming (7.6-15\%, all: $\mathrm{P} \leq 0.010)$. Individual IVD height to vertebral body height ratio was also greater at L2-L3 for soccer $(8.7 \%$, $\mathrm{P}=0.036)$ and $\mathrm{L} 3-\mathrm{L} 4$ for baseball $(7.6 \%, \mathrm{P}=0.011)$, compared to controls. Nucleus-

This article is protected by copyright. All rights reserved. 
annulus signal intensity ratio in the soccer group was $13 \%(\mathrm{P}=0.007)$ greater at the L2-L3 IVD compared to controls.

\section{IVD and spine properties in the matched sample}

When considering the matched sample, the only remaining significant differences were that the basketball group had greater average (9.0\%, $\mathrm{P}=0.024)$, L2-L3 (11\%, $\mathrm{P}=0.024)$, L3-L4 (13\%, $\mathrm{P}=0.004)$ and L4-L5 (7.8\%, $\mathrm{P}=0.043)$ IVD height (Table 1). Matched sample analyses revealed the basketball group had greater average lumbar (10\%, $\mathrm{P}=0.035), \mathrm{L} 3-\mathrm{L} 4$ (15\%, $\mathrm{P}=0.007)$ and L4-L5 (11\%, $\mathrm{P}=0.043)$ IVD height to vertebral body height ratio compared to controls (Table 3; Figure 2). Moreover, L2L3 IVD nucleus-annulus signal intensity ratio was $21 \%(\mathrm{P}=0.001)$ greater in the soccer group compared to controls (Table 3).

\section{All athletes pooled}

Supplemental Table S-1 presents the analyses of athletic groups pooled versus controls. Whilst a number of significant differences were present when comparing all athletes versus control, after analysing the matched pairs collective, few significant differences remained, with only a higher nucleus-annulus signal intensity ratio at L3/4 in athletes.

\section{Relationship between training variables and the spine}

After controlling for age, body height and sex (Table 4), training variables did not correlate with IVD height to vertebral body height ratio, but did correlate significantly, and negatively, with nucleus-annulus signal intensity ratio correlated significantly. These associations were however, weak explaining less than $1 \%$ of the variance in these parameters (i.e. $r<0.1$ ).

\section{DISCUSSION}

The main findings from this study were that basketball, swimming, baseball and soccer were associated with beneficial IVD parameters compared to controls. Specifically, soccer was associated with better IVD nucleus hydration (i.e. greater nucleus-annulus signal intensity ratio), whereas basketball, swimming, baseball and soccer groups all demonstrated greater IVD hypertrophy (i.e. greater IVD height to vertebral body height ratio). However, once variations in participant height were considered (i.e. matched sample analyses), only basketball and soccer were associated with beneficial IVD health. Greater career duration and training load were associated with worse IVD nucleus hydration (i.e. lower nucleus-annulus signal intensity ratio), but the magnitude of this association was weak.

Following matched sample analyses, basketball and soccer were the only remaining groups exhibiting beneficial IVD parameters (i.e. greater IVD hypertrophy or hydration) compared to controls. Whilst we are unaware of any previous studies that have examined the association between basketball and beneficial IVD characteristics, we previously hypothesized ${ }^{24}$ that sports involving ballistic and high-impact

This article is protected by copyright. All rights reserved. 
(jumping) loading patterns would be detrimental to IVD health, in accordance with higher rates of IVD degeneration seen in volleyball players ${ }^{25}$. This may imply that basketball could be detrimental to the IVD. Notably, the findings of the current study suggest that this prior hypothesis was incorrect and that basketball is associated with beneficial IVD adaptations. Notably, running, another sport involving high-impact IVD loading patterns, was shown to be associated with greater lumbar IVD hypertrophy compared to non-sporting referents ${ }^{15}$. Measurements of intradiscal pressures in running ${ }^{26}$, and therefore also presumably loading on the IVD during running in basketball and soccer, are likely within the potentially beneficial range of 0.3-1.2 $\mathrm{MPa}^{24}$. Potentially, the ability to maintain the lumbar lordosis during IVD loading may play a role in our current findings seen in these upright sports. Our observations regarding soccer conflicts with a previous study ${ }^{13}$ in which the sport was associated with greater lumbar IVD degeneration and pathologies compared to shooter referents (i.e. light-moderate physical activity). Comparison with this prior work is challenging as the prior study ${ }^{13}$ evaluated athletes more than 30 years after participation in elite sport and did not appear to implement blinding to athletic group during evaluation of MR images. Overall, our findings suggest that basketball and soccer may be associated with beneficial adaptations in the IVDs of younger athletes assessed at the time of their participation in the sport.

Our findings add to the emerging notion that specific types of exercise training may be capable of eliciting physiological responses in the lumbar IVD. This suggests that future studies should consider exercise training-based adaptations to the IVD and not limit outcomes to only markers of degeneration. Establishing exercise training that may be therapeutically utilised to improve IVD health, similar to that for muscle ${ }^{3}$ and bone ${ }^{4}$, has potential public health implications. For example, IVD degeneration is one postulated causal effect of chronic low back pain ${ }^{27}$; therefore, eliciting IVD hypertrophy through exercise training, similar to the use of progressive resistance exercise training for muscular atrophy, may reduce burden of disease.

The current study was strengthened by the blinded nature of MRI analyses, the diversity of sport exposure across the athlete groups, as well as the large sample size. The matched-analyses were also strengthened by accounting for back pain status, which reduced potential confounders regarding the deconditioning hypothesis. Furthermore, the use of level stratification accounted for potential variance in individual IVDs outcomes ${ }^{28}$. The limitations, however, should also be considered when interpreting these data. First, the cross-sectional design precludes the inference of causality between sport exposure and IVD characteristics. Second, the current study relied on subjective reports of sport involvement and thus the potential of recall bias cannot be entirely dismissed. Thirdly, a notable aspect of the current work is that the findings differed depending on whether the whole collective or matched-pairs were considered. Specifically, when the whole collective was considered, swimming and baseball were associated with better IVD characteristics, which contrasts with prior findings ${ }^{14,20}$. This underscores the importance of controlling for potential confounders when recruiting subjects for quantitative measurements of the IVD. Further, based on age, the sample recruited for the current study may not have reached IVD maturity and subsequent age-related degeneration, which may begin during the

This article is protected by copyright. All rights reserved. 
third decade of life ${ }^{29-31}$. However, this may also be viewed as a strength given that the age of the current sample allows the quantification of IVD health independent of the deleterious effects of the ageing process. Given the age of our participants, comparisons with studies of older adults is challenging. The findings of the current study cannot be generalized to conclude that specific sports have a general lifelong positive or detrimental effect on the IVD. Given the rate of tissue turnover in the IVD 32,33 , it is unclear how long an exercise intervention is required for changes to occur in the intervertebral disc. A recent 6 month randomised controlled trial of exercise ${ }^{34}$ led to equivocal results and further interventional studies are needed. Disc properties vary in a diurnal fashion ${ }^{35}$ and the reduction of spine length (and presumably disc height, hydration and disc T2) occurs to 50\% within the first hours of rising and is complete within the first 3-4 hours of rising ${ }^{36}$. Whilst we did not require scanning to occur at a specific time of day, most of the scanning occurred in the afternoon, after the young (university student) population had finished their classes for the day and we do not anticipate an impact of this on our findings. Future studies should control, or at least $\log$, the time of day relative to rising when assessing the IVD.

In conclusion, this study provides evidence of a positive effect of some, but not all, types of sport on the IVD in comparison to non-athletic controls. Specifically, basketball and soccer were associated with beneficial IVD parameters after accounting for variations in height across sporting groups. These data add to the body of evidence that specific types of exercise, when performed over a longer period, may be able to have a positive anabolic impact on the IVD.

\section{REFERENCES}

1. Wolff J. 1892. The law of bone remodeling (Das Gesetz der Transformation der Knochen). Springer-Verlag Berlin Heidelberg. 126 p.

2. Hawley JA. 2008. Specificity of training adaptation: time for a rethink? J. Physiol. 586(1):1-2.

3. Schoenfeld BJ, Ogborn D, Krieger JW. 2016. Effects of Resistance Training Frequency on Measures of Muscle Hypertrophy: A Systematic Review and Meta-Analysis. Sports Med. Auckl. NZ 46(11):1689-1697.

4. Bolam KA, van Uffelen JGZ, Taaffe DR. 2013. The effect of physical exercise on bone density in middle-aged and older men: A systematic review. Osteoporos. Int. 24(11):2749-2762.

5. Chan SCW, Ferguson SJ, Gantenbein-Ritter B. 2011. The effects of dynamic loading on the intervertebral disc. Eur. Spine J. 20(11):1796-1812.

6. Iatridis JC, MacLean JJ, Roughley PJ, Alini M. 2006. Effects of mechanical loading on intervertebral disc metabolism in vivo. J Bone Jt. Surg Am 88 Suppl $2: 41-6$.

7. Holm S, Nachemson A. 1983. Variations in the nutrition of the canine intervertebral disc induced by motion. Spine 8(8):866-874.

This article is protected by copyright. All rights reserved. 
8. Brisby H, Wei AQ, Molloy T, et al. 2010. The effect of running exercise on intervertebral disc extracellular matrix production in a rat model. Spine $\mathrm{Phila} \mathrm{Pa}$ 1976 35(15):1429-36.

9. Sasaki N, Henriksson HB, Runesson E, et al. 2012. Physical exercise affects cell proliferation in lumbar intervertebral disc regions in rats. Spine 37(17):14401447.

10. Ueta RHS, Tarini VAF, Franciozi CES, et al. 2018. Effects of Training and Overtraining on Intervertebral Disc Proteoglycans. Spine 43(1):E1-E6.

11. Luan S, Wan Q, Luo H, et al. 2015. Running exercise alleviates pain and promotes cell proliferation in a rat model of intervertebral disc degeneration. Int. J. Mol. Sci. 16(1):2130-2144.

12. Swärd L, Hellström M, Jacobsson B, et al. 1991. Disc degeneration and associated abnormalities of the spine in elite gymnasts. A magnetic resonance imaging study. Spine 16(4):437-443.

13. Videman T, Sarna S, Battié MC, et al. 1995. The long-term effects of physical loading and exercise lifestyles on back-related symptoms, disability, and spinal pathology among men. Spine 20(6):699-709.

14. Kaneoka K, Shimizu K, Hangai M, et al. 2007. Lumbar intervertebral disk degeneration in elite competitive swimmers: a case control study. Am. J. Sports Med. 35(8):1341-1345.

15. Belavý DL, Quittner MJ, Ridgers N, et al. 2017. Running exercise strengthens the intervertebral disc. Sci. Rep. 7:45975.

16. Belavy DL, Quittner M, Ridgers ND, et al. 2019. Beneficial intervertebral disc and muscle adaptations in high-volume road cyclists. Med. Sci. Sports Exerc. 51(1):211-217.

17. Marinelli NL, Haughton VM, Munoz A, Anderson PA. 2009. T2 relaxation times of intervertebral disc tissue correlated with water content and proteoglycan content. Spine 34(5):520-4.

18. Mitchell UH, Bowden JA, Larson RE, et al. 2020. Long-term running in middleaged men and intervertebral disc health, a cross-sectional pilot study. PloS One 15(2):e0229457.

19. Bowden JA, Bowden AE, Wang H, et al. 2017. In Vivo Correlates Between Daily Physical Activity and Intervertebral Disc Health. J. Orthop. Res..

20. Hangai M, Kaneoka K, Hinotsu S, et al. 2009. Lumbar intervertebral disk degeneration in athletes. Am. J. Sports Med. 37(1):149-155.

21. Videman T, Gibbons LE, Kaprio J, Battié MC. 2010. Challenging the cumulative injury model: positive effects of greater body mass on disc degeneration. Spine J. 10(1):26-31.

This article is protected by copyright. All rights reserved. 
22. Mala L, Maly T, Zahalka F, et al. 2015. Body composition of elite female players in five different sports games. J. Hum. Kinet. 45:207-215.

23. Benjamini Y, Hochberg Y. 1995. Controlling the false discovery rate: a practical and powerful approach to multiple testing. J. R. Stat. Soc. Ser. B 57(1):289-300.

24. Belavý DL, Albracht K, Bruggemann G-P, et al. 2016. Can Exercise Positively Influence the Intervertebral Disc? Sports Med. 46(4):473-485.

25. Bartolozzi C, Caramella D, Zampa V, et al. 1991. [The incidence of disk changes in volleyball players. The magnetic resonance findings]. Radiol. Med. (Torino) 82(6):757-760.

26. Wilke HJ, Neef P, Caimi M, et al. 1999. New in vivo measurements of pressures in the intervertebral disc in daily life. Spine 24(8):755-762.

27. Brinjikji W, Diehn FE, Jarvik JG, et al. 2015. MRI Findings of Disc Degeneration are More Prevalent in Adults with Low Back Pain than in Asymptomatic Controls: A Systematic Review and Meta-Analysis. AJNR Am. J. Neuroradiol. 36(12):2394-2399.

28. Hebelka H, Lagerstrand K, Brisby H, et al. 2019. The importance of level stratification for quantitative MR studies of lumbar intervertebral discs: a crosssectional analysis in 101 healthy adults. Eur. Spine J. 28(9):2153-2161.

29. Koeller W, Muehlhaus S, Meier W, Hartmann F. 1986. Biomechanical properties of human intervertebral discs subjected to axial dynamic compression--influence of age and degeneration. J. Biomech. 19(10):807-816.

30. Sether LA, Yu S, Haughton VM, Fischer ME. 1990. Intervertebral disk: normal age-related changes in MR signal intensity. Radiology 177(2):385-388.

31. Boos N, Weissbach S, Rohrbach H, et al. 2002. Classification of age-related changes in lumbar intervertebral discs: 2002 Volvo Award in basic science. Spine 27(23):2631-2644.

32. Sivan SS, Tsitron E, Wachtel E, et al. 2006. Aggrecan turnover in human intervertebral disc as determined by the racemization of aspartic acid. J Biol Chem 281(19):13009-14.

33. Sivan SS, Wachtel E, Tsitron E, et al. 2008. Collagen turnover in normal and degenerate human intervertebral discs as determined by the racemization of aspartic acid. J Biol Chem 283(14):8796-801.

34. Owen PJ, Miller CT, Rantalainen T, et al. 2020. Exercise for the intervertebral disc: a 6-month randomised controlled trial in chronic low back pain. Eur. Spine J.:in press. DOI 10.1007/s00586-020-06379-7.

35. Roberts N, Hogg D, Whitehouse GH, Dangerfield P. 1998. Quantitative analysis of diurnal variation in volume and water content of lumbar intervertebral discs. Clin Anat 11:1-8.

This article is protected by copyright. All rights reserved. 
36. Tyrrell AR, Reilly T, Troup JD. 1985. Circadian variation in stature and the effects of spinal loading. Spine 10(2):161-164.

\section{FIGURES}

Figure 1. Intervertebral disc (IVD) quantification.

After manually segmenting the IVD, height and signal intensity of the lumbar IVDs (L1-2 to L5-S1) was calculated. Furthermore, five IVD subregions from anterior to posterior were assessed (see inset). The vertebral bodies L1 to L5 were also traced and height measured. To assess the relative hydration of the nucleus the ratio of signal intensity in the nuclear region to the mean of anterior and posterior annulus (subregions 1 and 5) was calculated. To illustrate, we show two examples: the top most IVD in the scan has a signal intensity ratio (Ratiosi) of 2.8, implying the signal intensity in the central nuclear region is 2.8 times that of the average of the anterior and posterior aspects of the IVD. In the L4/5 IVD, the ratio is 4.7 , implying the nucleus is likely more hydrated in this IVD. As a measure of IVD hypertrophy, the height of the IVD was divided by that of the superior vertebral body. See Methods for more detail.

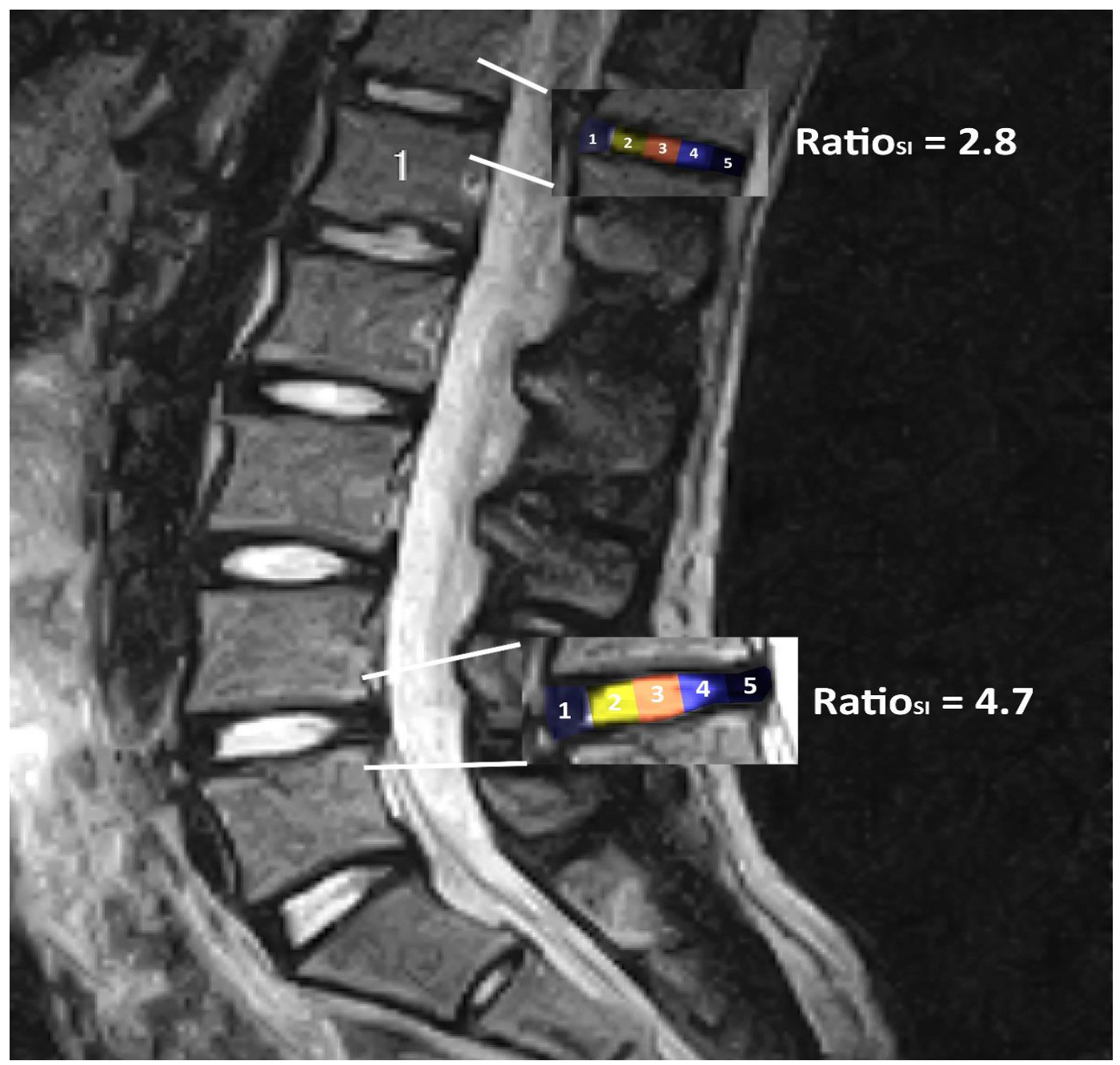

This article is protected by copyright. All rights reserved. 
Figure 2: Intervertebral disc parameters compared to control in the sporting groups in the whole collective (top panel) and matched sample (bottom panel)

To show relative differences, values are mean average lumbar IVD values in each athletic group divided by the mean in the control group. $* \mathrm{P}<0.05, \dagger \mathrm{P}<0.01$ compared to control. See Table 2 and Table 3 for more details.

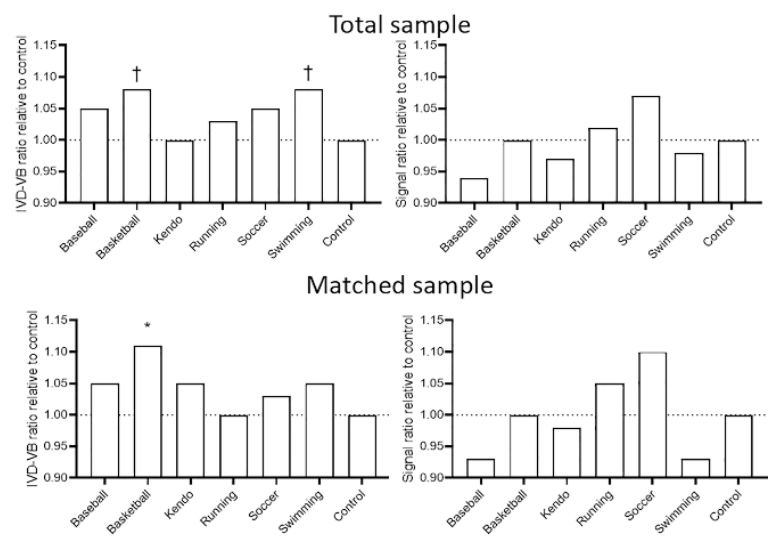

\section{Tables}

Table 1. Participant characteristics of the total $(n=379)$ and matched sample $(n=154)$.

\begin{tabular}{|c|c|c|c|c|c|c|c|}
\hline & $\begin{array}{c}\text { Basebal } \\
1\end{array}$ & $\begin{array}{c}\text { Basketba } \\
11\end{array}$ & Kendo & $\begin{array}{c}\text { Runnin } \\
\mathrm{g}\end{array}$ & $\begin{array}{c}\text { Socce } \\
r\end{array}$ & $\begin{array}{c}\text { Swimmin } \\
\mathrm{g}\end{array}$ & $\begin{array}{c}\text { Contro } \\
1\end{array}$ \\
\hline \multicolumn{8}{|c|}{ Total sample } \\
\hline $\mathrm{N}$ & 57 & 63 & 51 & 43 & 47 & 47 & 71 \\
\hline Age, yr & $20(1)$ & $20(1)$ & $20(1)$ & $19(1)$ & $19(0)$ & $19(1)$ & $19(1)$ \\
\hline Height, cm & $\begin{array}{l}174.8 \\
(6.7) \neq\end{array}$ & $\begin{array}{l}175.9 \\
(9.1) \div\end{array}$ & $\begin{array}{l}169.1 \\
(7.7) \dagger\end{array}$ & $\begin{array}{l}170.5 \\
(7.5)\end{array}$ & $\begin{array}{l}172.4 \\
(7.4)\end{array}$ & $\begin{array}{l}173.7 \\
(8.6)\end{array}$ & $\begin{array}{l}164.9 \\
(9.0)\end{array}$ \\
\hline $\begin{array}{l}\text { Back pain, } \\
\mathrm{n}(\%)\end{array}$ & $3(5.3)$ & $1(1.6)$ & $0(0.0)$ & $\begin{array}{c}5 \\
(11.6) \dagger\end{array}$ & $2(4.3)$ & $4(8.5)^{*}$ & $0(0.0)$ \\
\hline \multicolumn{8}{|l|}{$\begin{array}{l}\text { Level of } \\
\text { competitio } \\
n, n(\%)\end{array}$} \\
\hline \multicolumn{8}{|l|}{$\begin{array}{l}\text { Internation } \\
\text { al }\end{array}$} \\
\hline National & $\begin{array}{c}12 \\
(21.1)\end{array}$ & $28(44.4)$ & $\begin{array}{c}34 \\
(66.7)\end{array}$ & $\begin{array}{c}11 \\
(26.8)\end{array}$ & $\begin{array}{c}11 \\
(23.4)\end{array}$ & $36(76.6)$ & - \\
\hline Regional & $\begin{array}{c}45 \\
(79.0)\end{array}$ & $30(47.6)$ & $\begin{array}{c}16 \\
(31.4)\end{array}$ & $\begin{array}{c}24 \\
(58.5)\end{array}$ & $\begin{array}{c}33 \\
(70.2)\end{array}$ & $5(10.6)$ & - \\
\hline Other & $0(0.0)$ & $0(0.0)$ & $1(2.0)$ & $2(4.9)$ & $0(0.0)$ & $0(0.0)$ & - \\
\hline $\begin{array}{l}\text { Career } \\
\text { duration, } \\
\text { years }\end{array}$ & $\begin{array}{l}10.73 \\
(2.11)\end{array}$ & $\begin{array}{c}9.19 \\
(1.84)\end{array}$ & $\begin{array}{l}12.89 \\
(2.03)\end{array}$ & $\begin{array}{l}7.57 \\
(1.40)\end{array}$ & $\begin{array}{l}10.89 \\
(1.73)\end{array}$ & $\begin{array}{l}13.08 \\
(3.04)\end{array}$ & - \\
\hline
\end{tabular}

This article is protected by copyright. All rights reserved. 


\begin{tabular}{|c|c|c|c|c|c|c|c|}
\hline $\begin{array}{l}\text { Training, } \\
\text { days/week }\end{array}$ & $\begin{array}{c}5.87 \\
(0.32)\end{array}$ & $\begin{array}{c}5.42 \\
(0.67)\end{array}$ & $\begin{array}{c}5.88 \\
(0.43)\end{array}$ & $\begin{array}{c}5.45 \\
(0.63)\end{array}$ & $\begin{array}{c}5.85 \\
(0.34)\end{array}$ & $\begin{array}{c}6.02 \\
(0.15)\end{array}$ & - \\
\hline $\begin{array}{l}\text { Training, } \\
\text { hours/day }\end{array}$ & $\begin{array}{c}3.96 \\
(0.71)\end{array}$ & $\begin{array}{c}2.61 \\
(0.64)\end{array}$ & $\begin{array}{c}2.04 \\
(0.22)\end{array}$ & $\begin{array}{c}2.93 \\
(0.77)\end{array}$ & $\begin{array}{c}2.03 \\
(0.23)\end{array}$ & $\begin{array}{c}2.87 \\
(0.82)\end{array}$ & - \\
\hline $\begin{array}{l}\text { Lordosis } \\
\text { angle, } \\
\text { degrees }\end{array}$ & $\begin{array}{l}35.19 \\
(8.05)\end{array}$ & $\begin{array}{l}36.57 \\
(8.44)\end{array}$ & $\begin{array}{l}33.46 \\
(7.99)\end{array}$ & $\begin{array}{l}35.25 \\
(7.76)\end{array}$ & $\begin{array}{l}36.73 \\
(6.81)\end{array}$ & $\begin{array}{c}29.08 \\
(10.86) \div\end{array}$ & $\begin{array}{l}34.58 \\
(6.67)\end{array}$ \\
\hline \multicolumn{8}{|c|}{ IVD height, mm } \\
\hline AvLx & $\begin{array}{c}8.9 \\
(0.8) \dagger\end{array}$ & $9.4(0.8) \dagger$ & $\begin{array}{c}8.4 \\
(0.8)\end{array}$ & $\begin{array}{c}8.6 \\
(0.8)\end{array}$ & $\begin{array}{c}8.8 \\
(0.7) \dagger\end{array}$ & $8.9(0.7) \dagger$ & $\begin{array}{c}8.3 \\
(0.8)\end{array}$ \\
\hline L1-L2 & $\begin{array}{c}7.1 \\
(0.8) \dagger\end{array}$ & $7.5(1.0) \dagger$ & $\begin{array}{c}6.6 \\
(0.7)\end{array}$ & $\begin{array}{c}6.8 \\
(0.9)\end{array}$ & $\begin{array}{c}7.1 \\
(0.9)^{*}\end{array}$ & $7.0(0.9)$ & $\begin{array}{c}6.6 \\
(0.8)\end{array}$ \\
\hline L2-L3 & $\begin{array}{c}8.2 \\
(0.9) \dagger\end{array}$ & $8.8(1.0) \dagger$ & $\begin{array}{c}7.7 \\
(0.9)\end{array}$ & $\begin{array}{c}7.9 \\
(0.9)\end{array}$ & $\begin{array}{c}8.1 \\
(0.9) \dagger\end{array}$ & $8.1(0.9) \dagger$ & $\begin{array}{c}7.4 \\
(0.9)\end{array}$ \\
\hline L3-L4 & $\begin{array}{c}9.5 \\
(1.1) \dagger\end{array}$ & $\begin{array}{c}10.1 \\
(1.0) \dagger\end{array}$ & $\begin{array}{c}8.9 \\
(1.1)\end{array}$ & $\begin{array}{c}9.1 \\
(1.0)\end{array}$ & $\begin{array}{c}9.2 \\
(1.0)^{*}\end{array}$ & $9.4(0.9) \dagger$ & $\begin{array}{c}8.6 \\
(1.1)\end{array}$ \\
\hline L4-L5 & $\begin{array}{c}10.3 \\
(1.4) \dagger\end{array}$ & $\begin{array}{c}10.7 \\
(1.3) \dagger\end{array}$ & $\begin{array}{c}9.8 \\
(1.2)\end{array}$ & $\begin{array}{l}10.0 \\
(1.3)\end{array}$ & $\begin{array}{l}10.1 \\
(1)^{*}\end{array}$ & $\begin{array}{c}10.3 \\
(1.4)^{*}\end{array}$ & $\begin{array}{c}9.5 \\
(1.1)\end{array}$ \\
\hline L5-S1 & $\begin{array}{c}9.3 \\
(1.4)\end{array}$ & $9.9(1.6)^{*}$ & $\begin{array}{c}8.8 \\
(1.3)\end{array}$ & $\begin{array}{l}9.1 \\
(1.3)\end{array}$ & $\begin{array}{c}9.2 \\
(1.5)\end{array}$ & $9.7(1.1)$ & $\begin{array}{c}9.1 \\
(1.1)\end{array}$ \\
\hline \multicolumn{8}{|c|}{ IVD width, mm } \\
\hline AvLx & $\begin{array}{c}28.1 \\
(2.2) \dagger\end{array}$ & $\begin{array}{c}28.3 \\
(2.7) \dagger\end{array}$ & $\begin{array}{l}27.3 \\
(2.6)\end{array}$ & $\begin{array}{l}26.3 \\
(2.2)\end{array}$ & $\begin{array}{l}27.1 \\
(2.2)\end{array}$ & $27.2(2.5)$ & $\begin{array}{l}26.5 \\
(2.8)\end{array}$ \\
\hline L1-L2 & $\begin{array}{c}28.0 \\
(2.8) \dagger\end{array}$ & $\begin{array}{c}27.3 \\
(\mathbf{3 . 3})^{*}\end{array}$ & $\begin{array}{c}27.4 \\
(3.4)^{*}\end{array}$ & $\begin{array}{l}26.0 \\
(2.8)\end{array}$ & $\begin{array}{l}26.8 \\
(3.2)\end{array}$ & $25.0(3.6)$ & $\begin{array}{l}25.7 \\
(3.3)\end{array}$ \\
\hline L2-L3 & $\begin{array}{l}29.3 \\
(3.5)\end{array}$ & $\begin{array}{c}30.0 \\
(3.2) \dagger\end{array}$ & $\begin{array}{l}28.3 \\
(3.6)\end{array}$ & $\begin{array}{l}27.5 \\
(2.6)\end{array}$ & $\begin{array}{l}28.1 \\
(3.1)\end{array}$ & $27.9(3.4)$ & $\begin{array}{l}27.7 \\
(3.9)\end{array}$ \\
\hline L3-L4 & $\begin{array}{l}29.6 \\
(3.2)\end{array}$ & $\begin{array}{c}\text { 30.6 } \\
(3.5)^{*}\end{array}$ & $\begin{array}{l}29.0 \\
(3.4)\end{array}$ & $\begin{array}{l}28.1 \\
(3.0)\end{array}$ & $\begin{array}{l}29.1 \\
(2.8)\end{array}$ & $28.4(3)$ & $\begin{array}{l}28.7 \\
(3.4)\end{array}$ \\
\hline L4-L5 & $\begin{array}{l}29.2 \\
(2.9)\end{array}$ & $29.4(4.0)$ & $\begin{array}{l}28.4 \\
(3.4)\end{array}$ & $\begin{array}{l}27.7 \\
(2.9)\end{array}$ & $\begin{array}{l}28.4 \\
(3.5)\end{array}$ & $29.0(3.7)$ & $\begin{array}{l}27.8 \\
(3.3)\end{array}$ \\
\hline L5-S1 & $\begin{array}{c}24.3 \\
(3.0) *\end{array}$ & $\begin{array}{c}24.3 \\
(3.3)^{*}\end{array}$ & $\begin{array}{l}23.2 \\
(3.3)\end{array}$ & $\begin{array}{l}22.4 \\
(2.6) \\
\end{array}$ & $\begin{array}{l}23.3 \\
(2.8) \\
\end{array}$ & $\begin{array}{c}25.6 \\
(4.0) \dagger\end{array}$ & $\begin{array}{l}22.8 \\
(3.0)\end{array}$ \\
\hline \multicolumn{8}{|c|}{ Matched sample } \\
\hline $\mathrm{N}$ & 22 & 22 & 22 & 22 & 22 & 22 & 22 \\
\hline Age, yr & $20(1)$ & $20(1)$ & $20(1)$ & $19(1)$ & $19(0)$ & $19(1)$ & $20(2)$ \\
\hline Height, cm & $\begin{array}{l}171.5 \\
(4.6)\end{array}$ & $\begin{array}{c}171.8 \\
(5.0)\end{array}$ & $\begin{array}{l}171.4 \\
(4.7)\end{array}$ & $\begin{array}{l}171.5 \\
(5.6)\end{array}$ & $\begin{array}{l}171.3 \\
(5.5)\end{array}$ & $\begin{array}{c}171.9 \\
(5.6)\end{array}$ & $\begin{array}{l}171.5 \\
(5.7)\end{array}$ \\
\hline $\begin{array}{l}\text { Back pain, } \\
n(\%)\end{array}$ & $0(0.0)$ & $0(0.0)$ & $0(0.0)$ & $0(0.0)$ & $0(0.0)$ & $0(0.0)$ & $0(0.0)$ \\
\hline \multicolumn{8}{|l|}{$\begin{array}{l}\text { Level of } \\
\text { competitio } \\
n, n(\%)\end{array}$} \\
\hline $\begin{array}{l}\text { Internation } \\
\text { al }\end{array}$ & $0(0.00)$ & $2(9.09)$ & $\begin{array}{c}0 \\
(0.00)\end{array}$ & $1(4.55)$ & $\begin{array}{c}0 \\
(0.00)\end{array}$ & $3(13.64)$ & - \\
\hline National & $\begin{array}{c}7 \\
(31.82)\end{array}$ & $9(40.91)$ & $\begin{array}{c}17 \\
(77.27 \\
)\end{array}$ & $\begin{array}{c}6 \\
(27.27)\end{array}$ & $\begin{array}{c}6 \\
(27.27 \\
)\end{array}$ & $\begin{array}{c}17 \\
(77.27)\end{array}$ & - \\
\hline
\end{tabular}

This article is protected by copyright. All rights reserved. 


\begin{tabular}{|c|c|c|c|c|c|c|c|}
\hline Regional & $\begin{array}{c}15 \\
(68.18)\end{array}$ & $\begin{array}{c}11 \\
(50.00)\end{array}$ & $\begin{array}{c}5 \\
(22.73 \\
)\end{array}$ & $\begin{array}{c}15 \\
(68.18)\end{array}$ & $\begin{array}{c}16 \\
(72.73 \\
)\end{array}$ & $2(9.09)$ & - \\
\hline Other & $0(0.00)$ & $0(0.00)$ & $\begin{array}{c}0 \\
(0.00)\end{array}$ & $0(0.00)$ & $\begin{array}{c}0 \\
(0.00)\end{array}$ & $0(0.00)$ & - \\
\hline $\begin{array}{l}\text { Career } \\
\text { duration, } \\
\text { years }\end{array}$ & $\begin{array}{c}9.62 \\
(1.90)\end{array}$ & $\begin{array}{c}9.50 \\
(2.13)\end{array}$ & $\begin{array}{l}13.13 \\
(1.86)\end{array}$ & $\begin{array}{c}7.56 \\
(1.28)\end{array}$ & $\begin{array}{l}11.18 \\
(1.71)\end{array}$ & $\begin{array}{l}12.31 \\
(3.62)\end{array}$ & - \\
\hline $\begin{array}{l}\text { Training, } \\
\text { days/week }\end{array}$ & $\begin{array}{c}5.91 \\
(0.29)\end{array}$ & $\begin{array}{c}5.59 \\
(0.67)\end{array}$ & $\begin{array}{c}5.91 \\
(0.43)\end{array}$ & $\begin{array}{c}5.43 \\
(0.58)\end{array}$ & $\begin{array}{c}5.82 \\
(0.36)\end{array}$ & $\begin{array}{c}6.05 \\
(0.22)\end{array}$ & - \\
\hline $\begin{array}{l}\text { Training, } \\
\text { hours/day }\end{array}$ & $\begin{array}{c}4.05 \\
(0.72)\end{array}$ & $\begin{array}{c}2.75 \\
(0.55)\end{array}$ & $\begin{array}{c}2.05 \\
(0.21)\end{array}$ & $\begin{array}{c}2.93 \\
(0.66)\end{array}$ & $\begin{array}{c}1.99 \\
(0.12)\end{array}$ & $\begin{array}{c}2.98 \\
(0.80)\end{array}$ & - \\
\hline $\begin{array}{l}\text { Lordosis } \\
\text { angle, } \\
\text { degrees }\end{array}$ & $\begin{array}{l}35.59 \\
(8.20)\end{array}$ & $\begin{array}{l}37.21 \\
(7.88)\end{array}$ & $\begin{array}{l}31.62 \\
(7.05)\end{array}$ & $\begin{array}{l}35.45 \\
(7.33)\end{array}$ & $\begin{array}{l}38.55 \\
(6.45)\end{array}$ & $\begin{array}{l}31.32 \\
(9.95)\end{array}$ & $\begin{array}{l}33.36 \\
(5.37)\end{array}$ \\
\hline \multicolumn{8}{|c|}{ IVD height, mm } \\
\hline AvLx & $\begin{array}{c}8.8 \\
(0.9)\end{array}$ & $9.3(0.8) *$ & $\begin{array}{c}8.6 \\
(0.7)\end{array}$ & $\begin{array}{c}8.5 \\
(0.8)\end{array}$ & $\begin{array}{c}8.6 \\
(0.7)\end{array}$ & $8.7(0.6)$ & $\begin{array}{c}8.5 \\
(0.9)\end{array}$ \\
\hline L1-L2 & $\begin{array}{c}7.1 \\
(0.8)\end{array}$ & $7.3(0.9)$ & $\begin{array}{c}6.7 \\
(0.7)\end{array}$ & $\begin{array}{c}6.8 \\
(0.8)\end{array}$ & $\begin{array}{c}6.9 \\
(0.6)\end{array}$ & $7.0(0.8)$ & $\begin{array}{c}6.9 \\
(1.0)\end{array}$ \\
\hline L2-L3 & $\begin{array}{c}8.1 \\
(0.9)\end{array}$ & $8.6(1.0)^{*}$ & $\begin{array}{c}7.7 \\
(0.8)\end{array}$ & $\begin{array}{c}7.8 \\
(0.8)\end{array}$ & $\begin{array}{c}8.0 \\
(0.7)\end{array}$ & $8.0(0.8)$ & $\begin{array}{c}7.7 \\
(1.1)\end{array}$ \\
\hline L3-L4 & $\begin{array}{c}9.4 \\
(1.1)\end{array}$ & $\begin{array}{c}10.1 \\
(0.9) \dagger\end{array}$ & $\begin{array}{c}9.2 \\
(1.2)\end{array}$ & $\begin{array}{c}9.0 \\
(1.0)\end{array}$ & $\begin{array}{c}9.0 \\
(0.9)\end{array}$ & $9.3(0.7)$ & $\begin{array}{c}8.9 \\
(1.2) \\
\end{array}$ \\
\hline L4-L5 & $\begin{array}{l}10.0 \\
(1.5)\end{array}$ & $\begin{array}{c}10.7 \\
(1.0) *\end{array}$ & $\begin{array}{l}10.1 \\
(0.9)\end{array}$ & $\begin{array}{l}9.8 \\
(1.1)\end{array}$ & $\begin{array}{c}10 \\
(1.1)\end{array}$ & $9.8(1.4)$ & $\begin{array}{c}9.9 \\
(0.9)\end{array}$ \\
\hline L5-S1 & $\begin{array}{c}9.3 \\
(1.3)\end{array}$ & $9.9(1.4)$ & $\begin{array}{c}9.3 \\
(1.3)\end{array}$ & $\begin{array}{c}9.2 \\
(1.4)\end{array}$ & $\begin{array}{c}9.4 \\
(1.6)\end{array}$ & $9.6(1.2)$ & $\begin{array}{c}9.4 \\
(1.0)\end{array}$ \\
\hline \multicolumn{8}{|c|}{ IVD width, mm } \\
\hline AvLx & $\begin{array}{l}27.8 \\
(1.9)\end{array}$ & $27.6(1.8)$ & $\begin{array}{l}27.5 \\
(2.0)\end{array}$ & $\begin{array}{l}26.9 \\
(2.1)\end{array}$ & $\begin{array}{l}26.9 \\
(2.3)\end{array}$ & $26.8(2.2)$ & $\begin{array}{l}27.8 \\
(2.3)\end{array}$ \\
\hline L1-L2 & $\begin{array}{l}27.3 \\
(2.5)\end{array}$ & $26.4(2.3)$ & $\begin{array}{l}27.6 \\
(2.6)\end{array}$ & $\begin{array}{l}26.7 \\
(2.7)\end{array}$ & $\begin{array}{l}26.6 \\
(3.3)\end{array}$ & $25.1(3.4)$ & $\begin{array}{l}27.3 \\
(2.9) \\
\end{array}$ \\
\hline L2-L3 & $\begin{array}{l}28.9 \\
(2.5)\end{array}$ & $29.5(2.9)$ & $\begin{array}{l}28.4 \\
(3.0)\end{array}$ & $\begin{array}{l}28.2 \\
(2.4)\end{array}$ & $\begin{array}{l}28.4 \\
(3.2)\end{array}$ & $27.1(2.8)$ & $\begin{array}{l}28.6 \\
(3.4)\end{array}$ \\
\hline L3-L4 & $\begin{array}{l}29.8 \\
(3.2)\end{array}$ & $29.9(2.8)$ & $\begin{array}{l}28.5 \\
(3.1)\end{array}$ & $\begin{array}{l}28.4 \\
(3.0)\end{array}$ & $\begin{array}{l}28.4 \\
(2.8)\end{array}$ & $28.1(3.1)$ & $\begin{array}{l}29.7 \\
(2.8)\end{array}$ \\
\hline L4-L5 & $\begin{array}{l}28.8 \\
(2.1)\end{array}$ & $28.4(3.5)$ & $\begin{array}{l}28.8 \\
(2.9)\end{array}$ & $\begin{array}{l}28.3 \\
(3.0)\end{array}$ & $\begin{array}{c}28 \\
(3.6)\end{array}$ & $28.1(3.2)$ & $\begin{array}{l}28.8 \\
(3.5)\end{array}$ \\
\hline L5-S1 & $\begin{array}{l}24.1 \\
(3.5)\end{array}$ & $23.7(2.1)$ & $\begin{array}{c}24 \\
(3.1)\end{array}$ & $\begin{array}{l}22.9 \\
(2.9)\end{array}$ & $\begin{array}{c}23 \\
(2.6)\end{array}$ & $25.6(4.5)$ & $\begin{array}{l}24.3 \\
(3.2)\end{array}$ \\
\hline
\end{tabular}

Data are mean (standard deviation) or number (n; percentage). IVD: intervertebral disc. $* \mathrm{P}<0.05, \uparrow \mathrm{P}<0.01, \ddagger \mathrm{P}<0.001$ compared to control. AvLx: average of all lumbar levels. To mitigate risk of false positive, $\mathrm{P}$-values were adjusted by the false discovery rate method.

This article is protected by copyright. All rights reserved. 
Table 2. Intervertebral disc (IVD) parameters compared between athlete groups and control in the total sample $(n=379)$.

\begin{tabular}{|c|c|c|c|c|c|c|c|}
\hline & $\begin{array}{c}\text { Basebal } \\
1 \\
(n=57) \\
\end{array}$ & $\begin{array}{c}\text { Basketbal } \\
1 \\
(\mathrm{n}=63) \\
\end{array}$ & $\begin{array}{c}\text { Kend } \\
0 \\
(n=51) \\
\end{array}$ & $\begin{array}{c}\text { Runnin } \\
g \\
(n=43) \\
\end{array}$ & $\begin{array}{l}\text { Soccer } \\
(n=47)\end{array}$ & $\begin{array}{c}\text { Swimmin } \\
\mathbf{g} \\
(\mathrm{n}=47)\end{array}$ & $\begin{array}{c}\text { Contro } \\
1 \\
(n=71) \\
\end{array}$ \\
\hline \multicolumn{8}{|c|}{ Nucleus-annulus signal intensity ratio } \\
\hline $\begin{array}{l}\text { AvL } \\
x\end{array}$ & $\begin{array}{c}3.91 \\
(0.66)\end{array}$ & $4.19(0.66)$ & $\begin{array}{c}4.03 \\
(0.66)\end{array}$ & $\begin{array}{c}4.25 \\
(0.65)\end{array}$ & $\begin{array}{c}4.46 \\
(0.65)\end{array}$ & $4.07(0.65)$ & $\begin{array}{c}4.17 \\
(0.69)\end{array}$ \\
\hline $\begin{array}{l}\text { L1- } \\
\text { L2 }\end{array}$ & $\begin{array}{c}3.61 \\
(0.83)\end{array}$ & $4.02(0.84)$ & $\begin{array}{c}3.62 \\
(0.83)\end{array}$ & $\begin{array}{c}3.99 \\
(0.82)\end{array}$ & $\begin{array}{c}4.17 \\
(0.82)\end{array}$ & $3.59(0.83)$ & $\begin{array}{c}3.78 \\
(0.87)\end{array}$ \\
\hline $\begin{array}{l}\text { L2- } \\
\text { L3 }\end{array}$ & $\begin{array}{c}4.40 \\
(0.94)\end{array}$ & $4.35(0.95)$ & $\begin{array}{l}4.35 \\
(0.94)\end{array}$ & $\begin{array}{c}4.39 \\
(0.93)\end{array}$ & $\begin{array}{c}5.02 \\
(0.93) \\
\dagger\end{array}$ & $4.51(0.93)$ & $\begin{array}{c}4.40 \\
(0.98)\end{array}$ \\
\hline $\begin{array}{l}\text { L3- } \\
\text { L4 }\end{array}$ & $\begin{array}{c}4.63 \\
(1.04)\end{array}$ & $5.05(1.05)$ & $\begin{array}{c}4.88 \\
(1.04)\end{array}$ & $\begin{array}{c}4.89 \\
(1.03)\end{array}$ & $\begin{array}{c}5.19 \\
(1.03)\end{array}$ & $4.94(1.03)$ & $\begin{array}{c}4.96 \\
(1.09)\end{array}$ \\
\hline $\begin{array}{l}\text { L4- } \\
\text { L5 }\end{array}$ & $\begin{array}{c}3.88 \\
(1.27)\end{array}$ & 4.09 (1.28) & $\begin{array}{c}4.22 \\
(1.27)\end{array}$ & $\begin{array}{c}4.57 \\
(1.25)\end{array}$ & $\begin{array}{c}4.35 \\
(1.25)\end{array}$ & $4.13(1.26)$ & $\begin{array}{c}4.34 \\
(1.33)\end{array}$ \\
\hline $\begin{array}{l}\text { L5- } \\
\text { S1 }\end{array}$ & $\begin{array}{c}3.13 \\
(1.11)\end{array}$ & $3.54(1.12)$ & $\begin{array}{c}3.28 \\
(1.11)\end{array}$ & $\begin{array}{c}3.56 \\
(1.10)\end{array}$ & $\begin{array}{c}3.70 \\
(1.10)\end{array}$ & $3.20(1.10)$ & $\begin{array}{c}3.47 \\
(1.16)\end{array}$ \\
\hline \multicolumn{8}{|c|}{ IVD height to vertebral body height ratio } \\
\hline $\begin{array}{l}\text { AvL } \\
x\end{array}$ & $\begin{array}{c}0.40 \\
(0.04)\end{array}$ & $\begin{array}{c}0.41 \\
(0.04) \dagger\end{array}$ & $\begin{array}{c}0.38 \\
(0.04)\end{array}$ & $\begin{array}{c}0.39 \\
(0.04)\end{array}$ & $\begin{array}{c}0.40 \\
(0.04)\end{array}$ & $\begin{array}{c}0.41 \\
(0.04) \dagger\end{array}$ & $\begin{array}{c}0.38 \\
(0.05)\end{array}$ \\
\hline $\begin{array}{l}\text { L1- } \\
\text { L2 }\end{array}$ & $\begin{array}{c}0.31 \\
(0.04)\end{array}$ & $\begin{array}{c}0.33 \\
(\mathbf{0 . 0 4})^{*}\end{array}$ & $\begin{array}{c}0.30 \\
(0.04)\end{array}$ & $\begin{array}{c}0.31 \\
(0.04)\end{array}$ & $\begin{array}{c}0.32 \\
(0.04)\end{array}$ & $\begin{array}{c}0.36 \\
(\mathbf{0 . 0 4}) \dagger\end{array}$ & $\begin{array}{c}0.31 \\
(0.04)\end{array}$ \\
\hline $\begin{array}{l}\text { L2- } \\
\text { L3 }\end{array}$ & $\begin{array}{c}0.35 \\
(0.05)\end{array}$ & $\begin{array}{c}0.38 \\
(\mathbf{0 . 0 5}) \dagger\end{array}$ & $\begin{array}{c}0.34 \\
(0.05)\end{array}$ & $\begin{array}{c}0.35 \\
(0.05)\end{array}$ & $\begin{array}{c}\mathbf{0 . 3 6} \\
(\mathbf{0 . 0 5}) \\
*\end{array}$ & $\begin{array}{c}0.37 \\
(0.05) \dagger\end{array}$ & $\begin{array}{c}0.33 \\
(0.05)\end{array}$ \\
\hline $\begin{array}{l}\text { L3- } \\
\text { L4 }\end{array}$ & $\begin{array}{c}0.41 \\
(0.05)^{*}\end{array}$ & $\begin{array}{c}0.43 \\
(0.05) \dagger\end{array}$ & $\begin{array}{c}0.39 \\
(0.05)\end{array}$ & $\begin{array}{c}0.40 \\
(0.05)\end{array}$ & $\begin{array}{c}0.40 \\
(0.05)\end{array}$ & $\begin{array}{c}0.41 \\
(0.05) \dagger\end{array}$ & $\begin{array}{c}0.38 \\
(0.05)\end{array}$ \\
\hline $\begin{array}{l}\text { L4- } \\
\text { L5 }\end{array}$ & $\begin{array}{c}0.46 \\
(0.07)\end{array}$ & $0.46(0.07)$ & $\begin{array}{c}0.44 \\
(0.07)\end{array}$ & $\begin{array}{c}0.45 \\
(0.06)\end{array}$ & $\begin{array}{c}0.46 \\
(0.06)\end{array}$ & $0.47(0.06)$ & $\begin{array}{c}0.43 \\
(0.07)\end{array}$ \\
\hline $\begin{array}{l}\text { L5- } \\
\text { S1 } \\
\end{array}$ & $\begin{array}{c}0.43 \\
(0.07) \\
\end{array}$ & $0.45(0.07)$ & $\begin{array}{c}0.40 \\
(0.07) \\
\end{array}$ & $\begin{array}{c}0.42 \\
(0.07) \\
\end{array}$ & $\begin{array}{c}0.42 \\
(0.07) \\
\end{array}$ & $0.45(0.07)$ & $\begin{array}{c}0.43 \\
(0.08) \\
\end{array}$ \\
\hline
\end{tabular}

Data are mean (standard deviation). $* \mathrm{P}<0.05, \dagger \mathrm{P}<0.01$ compared to control. AvLx: average of all lumbar levels. To mitigate risk of false positive, P-values were adjusted by the false discovery rate method.

This article is protected by copyright. All rights reserved. 
Table 3 Intervertebral disc (IVD) parameters compared between athlete groups and control in the matched sample $(n=154)$

\begin{tabular}{|c|c|c|c|c|c|c|c|}
\hline & $\begin{array}{c}\text { Basebal } \\
1 \\
(n=22) \\
\end{array}$ & $\begin{array}{c}\text { Basketbal } \\
1 \\
(\mathrm{n}=22)\end{array}$ & $\begin{array}{c}\text { Kend } \\
0 \\
(n=22)\end{array}$ & $\begin{array}{c}\text { Runnin } \\
g \\
(n=22)\end{array}$ & $\begin{array}{l}\text { Soccer } \\
(n=22)\end{array}$ & $\begin{array}{c}\text { Swimmin } \\
\mathbf{g} \\
(\mathrm{n}=22)\end{array}$ & $\begin{array}{c}\text { Contro } \\
1 \\
(\mathrm{n}=22) \\
\end{array}$ \\
\hline \multicolumn{8}{|c|}{ Nucleus-annulus signal intensity ratio } \\
\hline $\begin{array}{l}\text { AvL } \\
x\end{array}$ & $\begin{array}{c}3.84 \\
(0.69)\end{array}$ & $4.14(0.65)$ & $\begin{array}{c}4.04 \\
(0.79)\end{array}$ & $\begin{array}{c}4.36 \\
(0.61)\end{array}$ & $\begin{array}{c}4.56 \\
(0.51)\end{array}$ & $3.85(0.62)$ & $\begin{array}{c}4.14 \\
(0.78)\end{array}$ \\
\hline $\begin{array}{l}\text { L1- } \\
\text { L2 }\end{array}$ & $\begin{array}{c}3.61 \\
(0.69)\end{array}$ & $4.02(0.89)$ & $\begin{array}{c}3.67 \\
(1.11)\end{array}$ & $\begin{array}{c}4.15 \\
(0.62) \\
\end{array}$ & $\begin{array}{c}4.19 \\
(0.68)\end{array}$ & $3.43(0.74)$ & $\begin{array}{c}3.80 \\
(0.86)\end{array}$ \\
\hline $\begin{array}{l}\text { L2- } \\
\text { L3 }\end{array}$ & $\begin{array}{c}4.31 \\
(1.06)\end{array}$ & $4.34(0.69)$ & $\begin{array}{c}4.47 \\
(0.84)\end{array}$ & $\begin{array}{c}4.46 \\
(0.77)\end{array}$ & $\begin{array}{c}5.36 \\
(0.68) \\
\dagger\end{array}$ & $4.31(0.80)$ & $\begin{array}{c}4.35 \\
(0.78)\end{array}$ \\
\hline $\begin{array}{l}\text { L3- } \\
\text { L4 }\end{array}$ & $\begin{array}{c}4.57 \\
(1.24)\end{array}$ & $4.87(0.57)$ & $\begin{array}{c}4.88 \\
(1.59)\end{array}$ & $\begin{array}{c}4.97 \\
(0.84)\end{array}$ & $\begin{array}{c}5.45 \\
(0.95)\end{array}$ & $4.62(1.14)$ & $\begin{array}{c}5.13 \\
(0.89)\end{array}$ \\
\hline $\begin{array}{l}\text { L4- } \\
\text { L5 }\end{array}$ & $\begin{array}{c}3.75 \\
(1.23)\end{array}$ & 4.07 (1.19) & $\begin{array}{c}4.16 \\
(1.24)\end{array}$ & $\begin{array}{c}4.63 \\
(1.35)\end{array}$ & $\begin{array}{c}4.50 \\
(1.09)\end{array}$ & $4.07(1.67)$ & $\begin{array}{c}4.35 \\
(1.51)\end{array}$ \\
\hline $\begin{array}{l}\text { L5- } \\
\text { S1 }\end{array}$ & $\begin{array}{c}3.06 \\
(1.23)\end{array}$ & $3.45(1.21)$ & $\begin{array}{c}3.28 \\
(1.12)\end{array}$ & $\begin{array}{c}3.73 \\
(1.11)\end{array}$ & $\begin{array}{c}3.54 \\
(0.77)\end{array}$ & $2.82(1.23)$ & $\begin{array}{c}3.14 \\
(1.21)\end{array}$ \\
\hline \multicolumn{8}{|c|}{ IVD height to vertebral body height ratio } \\
\hline $\begin{array}{l}\text { AvL } \\
x\end{array}$ & $\begin{array}{c}0.40 \\
(0.04)\end{array}$ & $\begin{array}{c}0.42 \\
(0.05) *\end{array}$ & $\begin{array}{c}0.40 \\
(0.04)\end{array}$ & $\begin{array}{c}0.38 \\
(0.04)\end{array}$ & $\begin{array}{c}0.39 \\
(0.04)\end{array}$ & $0.40(0.04)$ & $\begin{array}{c}0.38 \\
(0.05)\end{array}$ \\
\hline $\begin{array}{l}\text { L1- } \\
\text { L2 }\end{array}$ & $\begin{array}{c}0.32 \\
(0.04)\end{array}$ & $0.33(0.04)$ & $\begin{array}{c}0.30 \\
(0.03)\end{array}$ & $\begin{array}{c}0.31 \\
(0.03)\end{array}$ & $\begin{array}{c}0.31 \\
(0.03)\end{array}$ & $0.35(0.05)$ & $\begin{array}{c}0.31 \\
(0.05)\end{array}$ \\
\hline $\begin{array}{l}\text { L2- } \\
\text { L3 }\end{array}$ & $\begin{array}{c}0.36 \\
(0.05)\end{array}$ & $0.38(0.05)$ & $\begin{array}{c}0.34 \\
(0.04)\end{array}$ & $\begin{array}{c}0.34 \\
(0.05)\end{array}$ & $\begin{array}{c}0.35 \\
(0.04)\end{array}$ & $0.36(0.05)$ & $\begin{array}{c}0.33 \\
(0.06)\end{array}$ \\
\hline $\begin{array}{l}\text { L3- } \\
\text { L4 }\end{array}$ & $\begin{array}{c}0.40 \\
(0.05)\end{array}$ & $\begin{array}{c}0.44 \\
(\mathbf{0 . 0 5}) \dagger\end{array}$ & $\begin{array}{c}0.41 \\
(0.05)\end{array}$ & $\begin{array}{c}0.39 \\
(0.04)\end{array}$ & $\begin{array}{c}0.40 \\
(0.05)\end{array}$ & $0.41(0.05)$ & $\begin{array}{c}0.38 \\
(0.06)\end{array}$ \\
\hline $\begin{array}{l}\text { L4- } \\
\text { L5 }\end{array}$ & $\begin{array}{c}0.44 \\
(0.07)\end{array}$ & $\begin{array}{c}0.48 \\
(0.06) \dagger\end{array}$ & $\begin{array}{c}0.47 \\
(0.05)\end{array}$ & $\begin{array}{c}0.43 \\
(0.06)\end{array}$ & $\begin{array}{c}0.45 \\
(0.06)\end{array}$ & $0.44(0.07)$ & $\begin{array}{c}0.43 \\
(0.05)\end{array}$ \\
\hline $\begin{array}{l}\text { L5- } \\
\text { S1 }\end{array}$ & $\begin{array}{c}0.42 \\
(0.07)\end{array}$ & $0.46(0.08)$ & $\begin{array}{c}0.43 \\
(0.07)\end{array}$ & $\begin{array}{c}0.41 \\
(0.07)\end{array}$ & $\begin{array}{c}0.43 \\
(0.07)\end{array}$ & $0.44(0.07)$ & $\begin{array}{c}0.42 \\
(0.05)\end{array}$ \\
\hline
\end{tabular}

Data are mean (standard deviation). $* \mathrm{P}<0.05, \dagger \mathrm{P}<0.01$ compared to control. AvLx: average of all lumbar levels. To mitigate risk of false positive, $\mathrm{P}$-values were adjusted by the false discovery rate method.

Table 4: Correlation analyses between training variables and disc and spine variables

\begin{tabular}{|c|c|c|c|c|c|}
\hline Variable & $\begin{array}{c}\text { Lordosis } \\
\text { Angle } \\
\end{array}$ & $\begin{array}{c}\text { IVD } \\
\text { height }\end{array}$ & IVD width & $\begin{array}{c}\text { IVD-VB } \\
\text { ratio } \\
\end{array}$ & $\begin{array}{c}\text { Signal } \\
\text { ratio } \\
\end{array}$ \\
\hline \multicolumn{6}{|c|}{ Pearson's correlation co-efficient } \\
\hline Age & -0.053 & 0.138* & $0.168 \dagger$ & 0.099 & -0.177 \\
\hline Height & $-0.116 *$ & $0.580 \%$ & $0.654 \%$ & $0.200 \%$ & $0.212 \%$ \\
\hline $\begin{array}{l}\text { Career } \\
\text { duration }\end{array}$ & $-0.155 *$ & -0.044 & 0.073 & 0.070 & -0.175 \\
\hline
\end{tabular}

This article is protected by copyright. All rights reserved. 


\begin{tabular}{|c|c|c|c|c|c|}
\hline $\begin{array}{l}\text { Training } \\
(\mathrm{d} / \mathrm{wk})\end{array}$ & 0.017 & $-0.125 *$ & -0.121 & -0.039 & 0.073 \\
\hline Training (hr/d) & -0.026 & 0.075 & 0.030 & 0.093 & $-0.159 \dagger$ \\
\hline \multicolumn{6}{|c|}{ Pearson's partial correlation co-efficient (controlling for age, height and sex) } \\
\hline $\begin{array}{c}\text { Career } \\
\text { duration }\end{array}$ & -0.026 & -0.024 & $0.063 *$ & 0.032 & -0.096 \\
\hline $\begin{array}{l}\text { Training } \\
(\mathrm{d} / \mathrm{wk})\end{array}$ & -0.001 & -0.009 & 0.000 & 0.002 & 0.016 \\
\hline Training (hr/d) & -0.002 & 0.014 & -0.018 & 0.046 & -0.088 \\
\hline
\end{tabular}

$* \mathrm{P}<0.05, \dagger \mathrm{P}<0.01,+\mathrm{P}<0.001$. Given that body height and age correlate with a number of IVD and spine parameters, we focus on partial correlations for assessing the association between training variables and IVD parameters. Correlations are with average lumbar IVD variables.

This article is protected by copyright. All rights reserved. 